\title{
Sediment Transport Analysis of Sesayap River, Malinau District, North Kalimantan
}

\author{
Hardhi Rafsanjani \\ PT. Brantas Abipraya, Jakarta, INDONESIA \\ hardhi.raf@gmail.com
}

\begin{abstract}
River could have a very important role in improving the economy of a country when it is correctly and properly utilized. Nevertheless, rivers in Indonesia also have various problems, i.e. erosion and sedimentation which occur in many Indonesian rivers, one of it being the Sesayap River. Because of these problems, it is very important to do analysis on bed load transport, in order to find its amount in the existing river, so that optimal handling on the occurring erosion and sedimentation problems could be performed. This research aimed to obtain the amount of bed load transport in Sesayap River, and then compare it to the field condition. The approaches used in this bed load transport analysis were Einstein approach and Frijlink approach, with data required for the analysis, which was water level elevation, topography data, and sediment gradation data. Based on the result of conducted bed load transport analysis, the bed load transport analysis result in Seluwing area was higher than in the Port area. Therefore, sediment deposition or sedimentation would occur in the river segment on between both locations. Qualitatively or tendentiously, the above results showed consistency with what actually happened, or observed, in the field. If it assumed that the equivalent diameter of bed load is $8 \mathrm{~mm}$, the total of bed load transport on Seluwing area and Port area with Einstein approach are $1,582,263 \mathrm{~m}^{3}$ and $1,219,181 \mathrm{~m}^{3}$. Therefore, the sedimentary deposit per day could be calculated by calculating difference of bed load transport volume divided with total of the calculation day; which resulted sedimentary deposit per day of $2,859 \mathrm{~m}^{3}$. Whereas by using the Frijlink approach, the total of bed load transport on Seluwing area and Port area were of $1,391,940 \mathrm{~m}^{3}$ and $1,080,200 \mathrm{~m}^{3}$, and sedimentary deposit per day of $2,455 \mathrm{~m}^{3}$. Based on the results, in order to normalize the Sesayap River, the dredging needed is $2,859 \mathrm{~m}^{3} /$ day based on Einstein approach and $2,455 \mathrm{~m}^{3} / \mathrm{day}$ based on Frijlink approach.
\end{abstract}

Keywords: Sesayap River, sediment transport analysis, Einstein approach, Frijlink approach

\section{INTRODUCTION}

\subsection{Background}

Indonesia is a country with an abundance of natural resource, one of which is the rivers it owns. Rivers have strategic role in increasing the people welfare in a country, for example increasing the harvest with irrigation system, improving economy of the community by making the river as a tourist spot, or by using the river for fish farming.

Nevertheless, the river utilization could not be separated from problems that occur in the Indonesian rivers, particularly aggradation and degradation problems that happen in these rivers. Among others, aggradation causes the decreasing of water storage in the river, therefore lead to water overflow in the river itself. While degradation could cause destruction on river structure due to the land subsidence. Therefore, bed load transport analysis in Indonesian rivers is highly important, in order to find problems existed in the river, so that the handling could be done and river utilization in Indonesia could be more optimal.
One of the Indonesian rivers studied in this final project was Sesayap River. Sesayap River flows in the area of Regency of Malinau, North Kalimantan Province. Sesayap River has a quite important role in the economy of Malinau Regency, as for most of the areas in Malinau Regency are connected by rivers, so the river is widely used for transportation means and distribution of goods. However, the erosion and sedimentation process in Sesayap River has caused several environmental disturbances. One of it is in the river segment that flows in the capital city of Malinau Regency. The erosion and sedimentation disturbance occurred in the river segment lead to the formation of sedimentary island (local term "andras") that caused damage to the river cliffs which then threaten the surrounding land. If the erosion and sedimentation problems on the river segment are not immediately addressed, it will highly impact the economy of people in the Malinau Regency (Rafsanjani, 2017).

Based on the erosion and sedimentation problems occur in the Sesayap River, quantitative analysis needs to be conducted, related to the bed load 
transport in the river itself, so that appropriate and optimal handling to the erosion and sedimentation problems in Sesayap River could be done.

The objectives of the research are to determine the bed load transport formed in the Sesayap River, to find the condition of erosion and sedimentation occur in the Sesayap River, based on the conducted analysis, to compare result of the conducted analysis with condition on field, and to give recommendation to the local government of the Malinau Regency for further bed load transport analysis research.

The sediment transport analysis was focused only on bed load transport. Due to the limited particle gradation data, the gradation data of the sediment material was a varied hypothetic data, in form of gradation data ranged from small diameter to larger diameter, in order to discover the result suitability with the theoretical concept. The sediment transport analyses were carried out based on the bathymetrical measurement and water surface monitoring activities those were carried out from August 27 $7^{\text {th }}, 2016$ to December $31^{\text {th }}, 2016$. Community activities that affect the behavior of the bed load transport were not taken into account.

\section{PREVIOUS STUDIES}

\subsection{Study on Sedimentation Management of Sesayap River, Malinau Regency, North Kalimantan}

Cooperation Office of Engineering Faculty of Universitas Gadjah Mada (Lembaga Kerjasama Fakultas Teknik Universitas Gadjah Mada) (2016) conducted Study on Sedimentation Management of Sesayap River, Malinau Regency, North Kalimantan, in order to study the erosion-sedimentation processes, impact of the erosion-sedimentation processes to the sedimentary island or andras in the area of Malinau Regency's capital city. The study also intended to give suggestion or recommendation on the planning to handle the sedimentary island in the area of Malinau Regency's capital city.

The flows of rivers in Kalimantan, including Sesayap River, have an important role in supporting the economic development. Most of the areas in Malinau Regency are connected by the rivers; therefore river is widely used as transportation means and distribution of goods. In addition to passengers, the goods distributed are largely basic needs, the commodity of plantation, mining, and industry. It also supports the government program that is focusing on reducing isolation of the remote areas.
By assuming the equivalent diameter of bed load is 8 $\mathrm{mm}$, the bed load transport in Seluwing and Port areas, in consecutive, are ranged from 10,900 $12,500 \mathrm{~m}^{3} /$ day and $9,600-11,200 \mathrm{~m}^{3} /$ day. Therefore, it is advised to do dredging or withdrawal of sediment of $1,300 \mathrm{~m}^{3} /$ day. However, because the high dynamic of the river, the number could decrease or increase in accordance with the flow pattern dynamic and sediment supply from the upstream.

\subsection{Bed Load Transport Analysis in Code River}

Ledelsa (2006) conducted bed load transport analysis in the Code River. Code River is one of the main rivers that stretch on southern slope of Mount Merapi, passes through Sleman Regency, Yogyakarta City, and Bantul Regency, with river length of $40.2 \mathrm{~km}$ and watershed size of about $47.3 \mathrm{~km}^{2}$. This river has a large potency, because other than functioning as water resource, it is also transported sediment from the Mount Merapi. The analyzed bed load transport in this research was a total bed load transport summed from bed load transport and suspended transport. For bed load transport, the method used was Meyer-Peter and Muller method (MPM), while for the suspended transport, the method used was the Einstein method (1950).

For the bed load transport calculation, the data taken was the semi-monthly sample data in January 1995 in one of the reviewed sections. In this semi-monthly analysis, the bed sediment transport of $q b=0.2314$ $\mathrm{m}^{3} / \mathrm{s}$ and suspended sediment transport of $q s=$ $0.00041 \mathrm{~m}^{3} / \mathrm{s}$.

\subsection{Total Bed Load Transport Analysis of Dawas River of Musi Banyuasin Regency}

Pangestu \& Haki (2013) conducted the total bed load transport analysis on Dawas River, Musi Banyuasin Regency. The sedimentation caused siltation in the river. This happened because the sedimentation height reduces the water depth; if the siltation exceeds the river depth. It could clog the river flow and then causes flooding. River siltation could also lead to river overflow, if the high water discharge exceeds the river storage capacity. Therefore, several detailed analyses are needed in order to overcome on how far the sedimentation effects the flooding occurrence. Analysis of this research used several approaches, the Yang method (1996), Bagnold method (Bagnold, 1966), also Shen and Hung method (Shen \& Hung, 1971). The calculation was conducted on 5 different segment points, with distance of $100 \mathrm{~m}$ between the segments. The recapitulations of total sediment discharge data on all points are shown in Table 1. 
Table 1. Total sediment discharge

\begin{tabular}{llll}
\hline Location & $\begin{array}{l}\text { Yang Method } \\
\text { (ton/s) }\end{array}$ & $\begin{array}{l}\text { Bagnold } \\
\text { Method } \\
\text { (ton/s) }\end{array}$ & $\begin{array}{l}\text { Shen and } \\
\text { Hung Method } \\
\text { (ton/s) }\end{array}$ \\
\hline Point 1 & 0.0000794 & 0.0000794 & 0.00008 \\
Point 2 & 0.0000838 & 0.0000822 & 0.00008 \\
Point 3 & 0.0000705 & 0.0000691 & 0.00007 \\
Point 4 & 0.0000691 & 0.0000678 & 0.00007 \\
Point 5 & 0.0000738 & 0.0000724 & 0.00007 \\
Average & 0.00007532 & 0.00007418 & 0.00007 \\
\hline
\end{tabular}

By assuming that the unit weight of sediment is 1.8 ton $/ \mathrm{m}^{3}$, the average of sediment discharge presented in Table 1 are 0.000042, 0.000041, 0.000039 ton for Yang, Bagnold, and Shen and Hung method, respectively.

\section{GOVERNING EQUATIONS}

\subsection{Energy Grade Line Equation}

The energy grade line equation used the Bernoulli equation:

$$
h_{1}+\frac{P_{A}}{\gamma}+\frac{V_{1}^{2}}{2 g}=h_{2}+\frac{P_{B}}{\gamma}+\frac{V_{2}^{2}}{2 g}+h f
$$

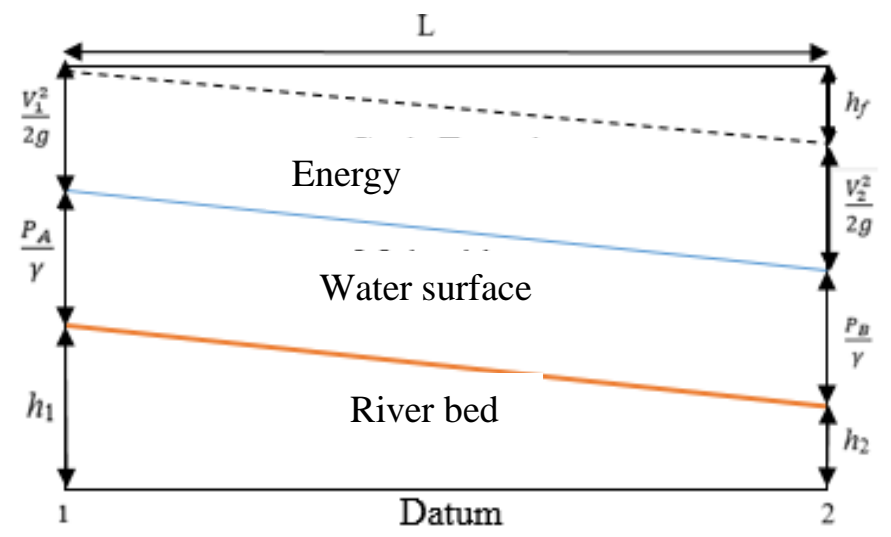

Figure 1. Energy grade line

\subsection{Hydraulic Radius of Cross Sectional Area}

The hydraulic radius of cross sectional area could be calculated with following equation:

$$
R=\frac{A}{P}=\frac{B \times H}{B+2 H}
$$

3.3 Manning and Chezy Coefficient

$$
C=\frac{1}{n} \times R^{\frac{1}{6}}
$$

\subsection{Einstein Approach}

According to Einstein (1950), the calculation procedure of bed load transport could be conducted with graphic on Figure 2, by calculating the value of $\psi^{*}$ :

$\psi^{*}=\frac{\Delta d_{35}}{\mu R S}$

with $\Delta=\frac{\rho s-\rho}{\rho}$

whereas $\mu$ is ripple factor, $R$ is hydraulic radius, $S$ is energy gradient, $d_{35}$ is diameter value for which $35 \%$ weight of the measured material is finer than its diameter value.

Then calculate the value of $\phi^{*}$ from Figure 2 and value of bed load transport could be calculated as follows.

$$
\phi^{*}=\frac{\tau_{b}}{\sqrt{\left(s_{s}-1\right) \times g \times d^{3}}}
$$

whereas $\tau_{b}$ is bed load transport with unit of $\mathrm{m}^{3} / \mathrm{s} / \mathrm{m}$

Note: for transport, the $d_{35}$ was still used, but the basic roughness calculation used the $d_{65}$ :

$$
C=18 \log \frac{12 \times R}{d_{65}}
$$




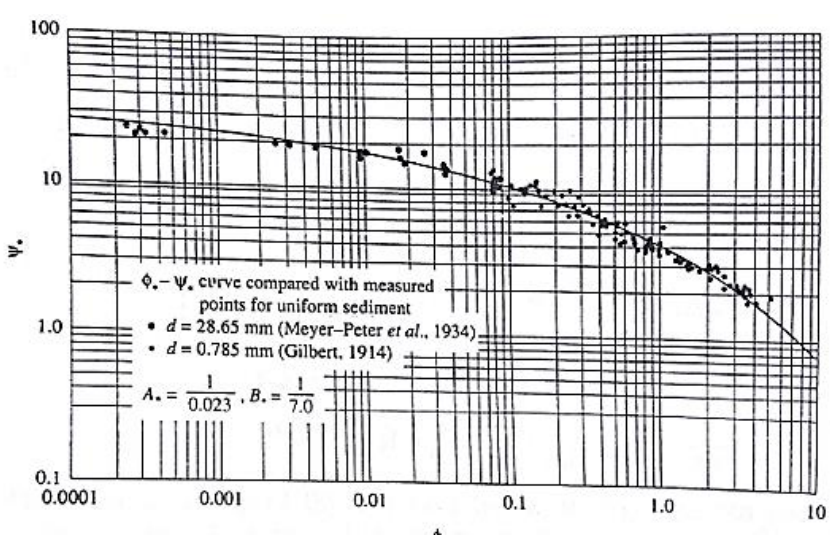

Figure 2. Graph of $\Psi^{*}$ vs $\phi^{*}$, Einstein (1950)

\subsection{Frijlink Approach}

Frijlink (1952) made a simple fit of the formulae of Meyer-Peter and Muller and that of Einstein in a practical approach. The proposed dimensionless bed load formula was as follows:

$\psi^{*}=\frac{\Delta d m}{\mu R S}$

$\phi^{*}=\frac{\tau_{b}}{d m \times \sqrt{g \times \mu \times R \times I}}$

whereas $d m$ is diameter value for which $50 \%$ weight of the measured material is finer than its diameter value, and $\tau_{b}$ is bed load transport with unit $\mathrm{m}^{3} / \mathrm{s} / \mathrm{m}$.

The Frijlink method considered ripple factor which can be calculated based on roughness coefficient of Chezy as written below:

$\mu=\left(\frac{C}{C_{d_{90}}}\right)^{\frac{3}{2}}$

whereas $C$ is total Chezy coefficient (grain roughness + dimension):

$C=18 \log \frac{12 \times R}{k}\left(\mathrm{~m}^{1 / 2} / \mathrm{s}\right)$

$C_{d_{90}}$ is Chezy coefficient related to roughness (represented by $d_{90}$ ):

$C_{d_{90}}=18 \log \frac{12 \times R}{d_{90}}$

Bed load transport with Frijlink approach could be methodology

\subsection{Data Availability}

The data used was secondary data obtained from various sources. This includes the followings:

\section{a) Water Surface Elevation}

The water level elevation data was obtained from the data of AWLR (Automatic Water Level Recorder) that was installed on two points in the Sesayap River, which were the Seluwing area and Port area. The water level elevation on AWLR recorded changes in water elevation every few minutes, but this research used hourly water level elevation data taken on each minute of the hour.

\section{b) Topography data}

Topography data of Sesayap River was obtained from the Study on Sedimentation Management of Sesayap River, Malinau Regency, and North Kalimantan Province. Measurement and drawing of the river topography have been conducted by fixing the reference point system tied with other bench marks that were more standard. About 5 bench marks were installed along the right bank of Sesayap River in Malinau City. Descriptions on the five bench marks are shown in Table 2.

Table 2. Bench Mark Point

\begin{tabular}{llll}
\hline \multirow{2}{*}{ Nomenclature } & \multicolumn{3}{c}{ Location } \\
\cline { 2 - 3 } & \multicolumn{2}{c}{ Coordinat $(\mathrm{m})$} & \multirow{2}{*}{ Altitude $(\mathrm{m})$} \\
\cline { 2 - 4 } & $\mathrm{X}$ & $\mathrm{Y}$ & 7994 \\
BM-01 & 458728.9 & 397233.4 & 9094 \\
BM-02 & 458070.03 & 396750.1 & 10093 \\
BM-03 & 457694.37 & 396441.6 & 16419 \\
BM-04 & 457487.75 & 395473.1 & 15932 \\
BM-05 & 457281.69 & 395263.2 & \\
\hline
\end{tabular}

c) Bed load material gradation data

Bed load material gradation data in this research was hypothetical gradation data. This was because testing on the bed load material has not been done due to various factors, among others, was high cost and a quite long period of time. To ease the analysis when the sediment characteristic test is conducted, and also to find suitability of conducted analysis with the theoretical concept, the hypothetical bed load graduation data were varied, which were three types of different gradation data ranged from small diameter to large diameter.

\subsection{River Hydraulic Analysis}

After the data was collected, then the hydraulic of Sesayap River was analyzed on the reviewed point. 
The steps of the conducted hydraulic analysis were as follows:

a) Determine water characteristic/trait and bed load material in the form of $\rho$ and $\rho_{\mathrm{s}}$ values.

b) Make cross section on points where the AWLR was installed, which were the Seluwing and Port areas.

c) Determine the Manning coefficient $n$ value.

d) Determine the energy gradient $S$ value.

e) Determine the water level height $H$ based on the water level elevation data and topography data.

f) Determine the hydraulic radius of cross section $R$ from Equation 2.

g) Determine the Chézy coefficient $C$ dan $C_{90}$ from Equation 3 and Equation 10.

\subsubsection{Bed Load Transport Analysis}

After the river hydraulic river was carried out, the next phase was the calculation of bed load transport. Calculation of the bed load transport in this research was conducted by two approaches, the Einstein approach, and the Frijlink approach. Steps on the conducted bed load transport calculation are as follows:

Einstein approach:

a) Calculate $\mu$ value from Equation 8 .

b) Calculate $\psi *$ value from Equation 5 .

c) Determine the transport intensity value $\phi^{*}$ from Figure 3.

d) Calculate bed load transport $\tau_{b}$ from equation 6 .

Frijlink approach:

a) Calculate $\mu$ value from Equation 8

b) Calculate $\psi *$ value from Equation 11 .

c) Determine the transport intensity value $\phi^{*}$ from Figure 3.

d) Calculate bed load transport $\tau_{b}$ from Equation 12 .

\subsection{Recapitulation of Analysis Result}

The conducted analysis was bed load transport hourly analysis from August $27^{\text {th }}, 2016$ to December 2016, with bed load material gradation data used was varied hypothetical data in form of three different gradation data ranged from small diameter to large diameter. After the bed load transport analysis was conducted, the analysis result was being recapped every month and being arranged based on the bed load material gradation data on the analysis.

\section{RESULT AND DISCUSSION}

\subsection{General}

The bed load transport analysis in Sesayap River was conducted on the set points, which was the Seluwing area and Port area. More details are shown in Figure 3.

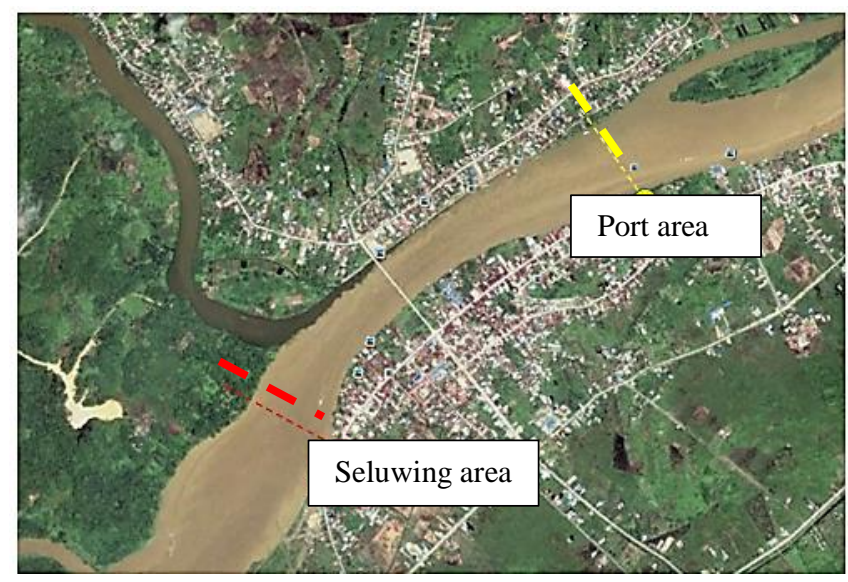

Figure 3. Research location

Coordinates of the AWLR on point of Seluwing and Port are shown in Table 3.

Table 3. AWLR coordinate in Seluwing area and Port area

\begin{tabular}{llll}
\hline \multirow{2}{*}{ AWLR } & \multicolumn{2}{l}{ Coordinate $(\mathrm{m})$} & Altitude $(\mathrm{m})$ \\
\cline { 2 - 3 } & $\mathrm{X}$ & $\mathrm{Y}$ & \\
\hline Seluwing area & 457663 & 396439 & \multirow{2}{*}{1769} \\
Port area & 459163 & 397376 & \\
\hline
\end{tabular}

Based on Table 3, it is known that distance between AWLR Seluwing and AWLR Port was approximately $1769 \mathrm{~m}$ or about $1.8 \mathrm{~km}$. This distance number then was used for the conducted hydraulic analysis. Due to a large amount of the analyzed data, the writing of the calculation on this chapter would take one of the analyzed data, which is August $27^{\text {th }}, 2016$; and the bed load material gradation data is the Gradation Data A.

\subsection{River Hydraulic Analysis}

The numbers of data on August $27^{\text {th }}, 2016$, at 00.00 are as follows:

a) Water level elevation on Seluwing area and port area were of $4.54 \mathrm{~m}$ and 3.42

b) Cross section width for the Seluwing area and Port were $282.03 \mathrm{~m}$ and $268.87 \mathrm{~m}$

Analysis results on river hydraulic are as follows:

a) Energy gradient $S=0.00063$ 
b) Water level height $H$ on the area of Seluwing and Port were of $2.78 \mathrm{~m}$ and $2.43 \mathrm{~m}$

c) Hydraulic radius $R$ of Seluwing area and Port area were of $2.73 \mathrm{~m}$ and $2.39 \mathrm{~m}$

d) Value of roughness coefficient Chézy $C$ and $C_{90}$ on Seluwing were of 39.45 and 70.05

e) Value of roughness coefficient Chézy $C$ and $C_{90}$ on Port area were of 38.53 and 69.01

\subsection{Bed Load Transport Analysis}

Results of the bed load transport analysis are as follows:

a) With Einstein approach, the total of bed load transport in Seluwing area was of $6514.4 \mathrm{~m}^{3}$ and Port area was of $5642.6 \mathrm{~m}^{3}$

b) With Frijlink approach, the total of bed load transport in Seluwing area was of $5104.6 \mathrm{~m}^{3}$ and Port area was of $4382.1 \mathrm{~m}^{3}$

\subsection{Total Analysis Result}

After the analyses from August $27^{\text {th }}, 2016$ to December 31, 2016, were conducted, results of each calculation were being recapped. Based on the bed load transport analysis result, the bed load transport analysis result on Seluwing area was higher than in the Port area. Therefore, sedimentation or sediment deposition would occur on between the river segments of both locations. Qualitatively or tendentiously, the above results showed consistency on what actually occurs or being observed on the field. The analysis result that based on three-bed load characteristic variations (Figure 5) and two approach formulas (Einstein and Frijlink) is resumed on Figure 6.

Based on the graphic, if it is assumed that the equivalent diameter of the bed load is $8 \mathrm{~mm}$, total of bed load transport in Seluwing area and Port area, using the Einstein approach, are $1582263 \mathrm{~m}^{3}$ and $1219181 \mathrm{~m}^{3}$. Therefore, the sedimentary deposit per day could be calculated, by calculating the difference of bed load transport divided with transport day total, so that the sedimentary deposit per day is of 2858.9 $\mathrm{m}^{3}$. While by using the Frijlink result, the total of bed load transport on Seluwing area and Port area are $1391940 \mathrm{~m}^{3}$ and $1080200 \mathrm{~m}^{3}$, and the sedimentary deposit per day is of $2454.6 \mathrm{~m}^{3}$. Based on these results, in order to normalize the Sesayap River, the dredging needed is $2858.9 \mathrm{~m}^{3} /$ day based on Einstein approach and $2454.6 \mathrm{~m}^{3} /$ day based on Frijlink approach.

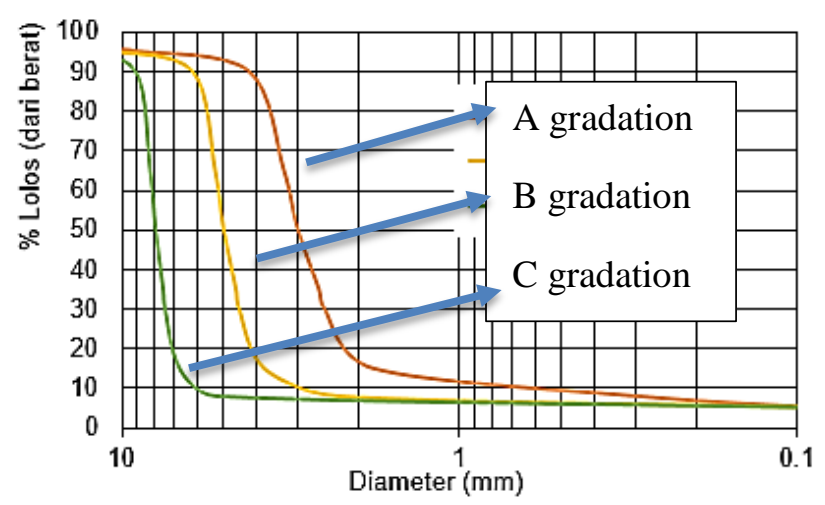

Figure 5. Sediment gradation data

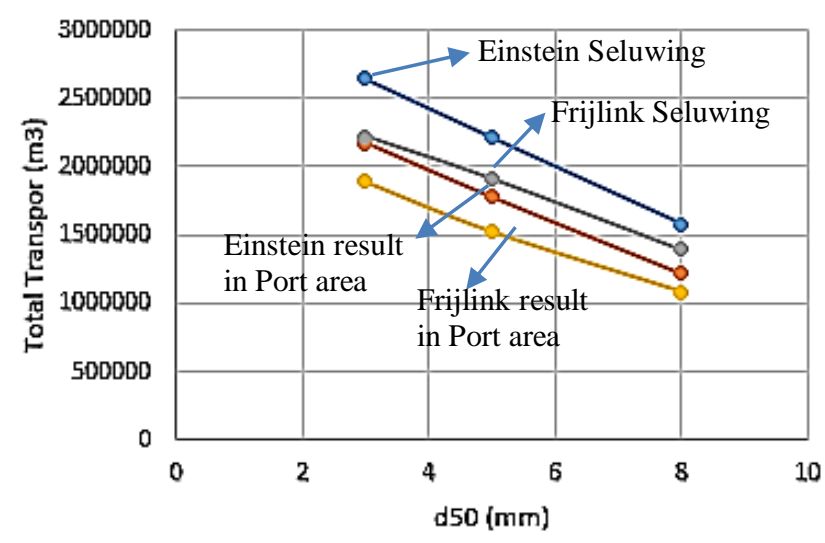

Figure 6. Bed load result in Seluwing area and Port area

\subsection{Comparison of Analysis Result to Condition on Field}

According to the observation on field, it was seen that there has been deposition on the area between Seluwing and Port. Based on the conducted calculation, the volume of depositary occurred per day has been discovered. However, it is necessary to review the occurring changes in river bed from the existing topography data, by comparing the 2008 and the 2016 topography data, in order to discover in more detail the erosion-sedimentation trait that occurs in the Sesayap River.

To find the river bed changes in Sesayap River based on the conducted analysis, area between Seluwing and port were being reviewed. Five cross sections were made on the reviewed locations. Cross sections in this location were reviewed based on the 2008 topography data and 2016 topography data. The location of the cross sections could be seen in Figure 7. 


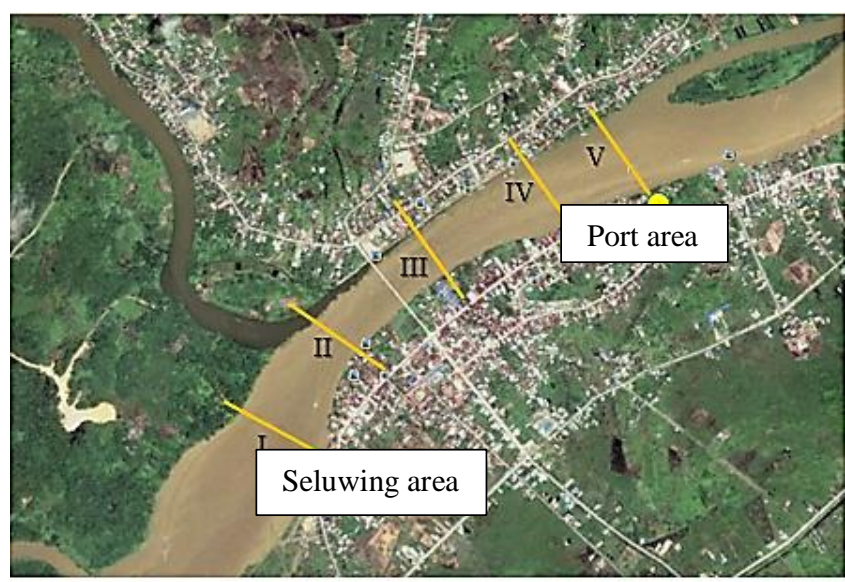

Figure 7. Cross section area

The depository volume and eroded material volume were calculated based on the 2008 topography data and 2016 topography data. According to the result of the conducted analysis, it was known that the event happened on the cross section location were degradation on the left part of the river, and aggradation on the center part and right part of the river. If elevation -2 references are used, the volume of bed load material eroded during the eight year period is $41835 \mathrm{~m}^{3}$ or $14.32 \mathrm{~m}^{3} /$ day; whereas the depository volume occurred during the eight year period is $116996.75 \mathrm{~m}^{3}$ or $40.07 \mathrm{~m}^{3} /$ day. This considerable difference between the analysis result and the condition on field was due to the many factors that influenced the bed load transport, such as the sand mining activities in Sesayap River, or other activities that affected the occurring bed load transport. In order to really get an accurate result, a considerably lengthy process and analysis from various angle needed to be conducted. For example, periodic monitoring on river topography changes and then monitoring on activities that affected the bed load volume in Sesayap River.

\subsection{Admission of Einstein and Frijlink Approaches}

General descriptions of Einstein and Frijlink approaches are shown in Table 4. It could be seen that there are several limitations of the approach used for the bed load transport sediment analysis, which is on the diameter ranges used for analysis. Also, it is seen from Figure 2 and Figure 3 that the bed load transport analysis with Einstein and Frijlink approaches were very depended on the relation graphic of bed load intensity $(\Phi)$ and flow intensity ( $\Psi)$ on each approaches graphics. According to the graphics, numbers on both the Einstein and Frijlink graphics were limited on some certain amount. Therefore, in certain conditions, the Einstein and Frijlink approaches could not calculate load transport for value $\phi$ and $\Psi$ that are not available on the graphics. It was also known from the Table 4, that the Einstein and Frijlink approaches were obtained from laboratory experiment. Hence, the bed load transport analysis on natural rivers needs to be conducted with other different approaches, in order to discover which approach is the most suitable for the erosionsedimentation pattern in the river.

Table 4. Einstein and Frijlink general descriptions

\begin{tabular}{lllll}
\hline Researcher & Method & $\begin{array}{l}\text { Range } \\
\text { of } d\end{array}$ & $\begin{array}{l}\text { Used } \\
d\end{array}$ & Information \\
\hline $\begin{array}{l}\text { Einstein } \\
(1942)\end{array}$ & $\begin{array}{l}\text { Probabi } \\
\text { listic }\end{array}$ & $\begin{array}{l}0.3<d \\
<28\end{array}$ & $d_{35}$ & $\begin{array}{l}\text { Empiric/Labor } \\
\text { atory } \\
\text { mm }\end{array}$ \\
& & $0.4<d$ & & $\begin{array}{l}\text { experiment } \\
\text { Laboratory } \\
\text { experiment } \\
\text { arijlink }\end{array}$ \\
$(1952)$ & - & $<28$ & $d_{50}$ & $\begin{array}{l}\text { and field } \\
\text { experiment }\end{array}$ \\
\hline
\end{tabular}

\section{CONCLUSIONS AND SUGGESTIONS}

\subsection{Conclusions}

The conclusions of this research are as follows:

a) By assuming the grain equivalent diameter of 8 $\mathrm{mm}$, the volume of load transport on Seluwing area and Port area from August $27^{\text {th }}, 2016$ to December 31,2016 , was $1582263 \mathrm{~m}^{3}$ and $1219181 \mathrm{~m}^{3}$ by using Einstein Approach; and $1391940 \mathrm{~m}^{3}$ and $1080200 \mathrm{~m}^{3}$ by using the Frijlink approach.

b) Based on the conducted analysis, condition occurred on the research location is an aggradation. This result was compatible with condition on the field because, in the research location, sedimentary island (andras) was formed.

c) Based on the calculation of deposited and eroded volume of Sesayap River and by comparing the 2016 topography data to the 2008 topography data at -2.00 elevation, the eroded load material volume during eight year period was of $41835 \mathrm{~m}^{3}$ or 14.32 $\mathrm{m}^{3} /$ day. Whereas for the deposited volume formed during the eight year period was of $116996.75 \mathrm{~m}^{3}$ or $40.07 \mathrm{~m}^{3} /$ day. The considerable difference between the analysis result and the condition on field was due to the factors those influenced the calculation. This field condition arises in the form of sand mining activities along the river reach being studied.

\subsection{Suggestions}

Some suggestions can be useful for the improvement of this research are as follows:

a) In this research, the load material gradation data was hypothetical data, due to the material gradation 
on Sesayap River was not been tested. It is expected that there will be further research that would be related to the bed load material gradation so that the conducted bed load transport analysis could be more accurate.

b) In order to really obtain an accurate result on load volume change in the field, analysis from various angle and considerably lengthy process are needed to be conducted. For example, the periodic monitoring on river topography changes and then monitoring on activities that affected the load volume in Sesayap River.

c) This study only conducted analysis for about 4 months. Therefore, the following analysis that used ARR and AWLR monitoring result in longer periods are still needed, so that the estimation on load transport could be done more accurately.

d) This study used the Einstein and Frijlink formula for bed load transport analysis which is considered still limited and less verified. Further analysis using the newer formula is advisable.

\section{REFERENCES}

Bagnold, R., 1966. An approach to the sediment transport problem from general physics, Washington D.C: Geological Survey Professional Paper.

Cooperation Office of Engineering Faculty of Universitas Gadjah Mada (Lembaga Kerjasama Fakultas Teknik Universitas Gadjah Mada), 2016. Sedimentation Management Report in Sesayap River, Malinau Regency, North Kalimantan, Yogyakarta: Cooperation Office of Engineering Faculty of
Universitas Gadjah Mada (Lembaga Kerjasama Fakultas Teknik Universitas Gadjah Mada).

Einstein, H. A., 1950. The Bed-Load Function for Sediment Transportation in Open Channel Flows. In: Soil Conservation Service. pp. 1-31.

Frijlink, H. C., 1952. Discussion of Bed Load Transport Formula, Delft: Delft Hydraulics.

Ledelsa, E., 2006. Transport Sediment Analysis in Code River, Yogyakarta: Department of Civil and Engineering Universitas Gadjah Mada.

Pangestu, H. \& Haki, H., 2013. Analisis Angkutan Sedimen Total pada Sungai Dawas Kabupaten Musi Banyuasin [Analysis of Total Bed Sediment Transport in Dawas River, Banyuasin Regency]. Jurnal Teknik Sipil dan Lingkungan, 1(1).

Rafsanjani, H., 2017. Bed Load Analysis of Sesayap River, Malinau District, North Kalimantan Province, Yogyakarta: Undergraduate Project, Department of Civil and Environmental Engineering, Faculty of Engineering, Universitas Gadjah Mada.

Shen, H. W. \& Hung, C. S., 1971. An Engineering Approach to Total Bed Material Load by Regression Analysis. Berkeley.

Yang, C. T., 1996. Sediment Transport: Theory and Practice. New York, U.S.A.: McGraw-Hill. 